\title{
Perception on Acceptability of Nigerian Females on Beaded Jewellery Empowerment for Entrepreneurial Development
}

\author{
Taibat Tunrayo Adebisi*)1, Oluwafeyikemi Edith Bashorun², Shakirat Odunayo \\ Abdulkadir ${ }^{3}$, Banke Adebola Adepoju ${ }^{4}$ \\ ${ }^{1,3,4}$ Department of Home Economics and Food Science, Faculty of Home Economics \\ and Food Science, University of Ilorin, Ilorin, Nigeria \\ ${ }^{2}$ Department of Home Science and Hospitability Management, College of Agriculture, \\ Olabisi Onabanjo University, Ayetoro Campus, Ayetoro, Nigeria.
}

*Corresponding author: adebisi.tt@unilorin.edu.ng

\begin{abstract}
The study investigates the perception of acceptability of Nigerian females on beaded jewellery empowerment for entrepreneurial development. Four research questions with two null hypotheses were formulated and tested. Descriptive research of a survey type was adopted. 70 female students from fine and applied arts and 70 female adults from Ilorin metropolis, Nigeria were used. Proportional sampling technique was used to select the 140 participants. A selfstructured questionnaire with six sections was used to seek information from them. Data collected were analyzed using frequency and percentage while the hypotheses were tested using chi-square at 0.05 level of significance. Based on the findings, the participants perceived that: beads are the major materials used, the skill might occupy a female's time and generate income. Profits realized can be substantial for the producers and sellers. The six self -samples were accepted based on colour, design, texture and shape. It can be concluded that the skill might be acquired, used to curb female idleness and unemployment. Among the recommendations stated are: bead crafts should be included in the curriculum at all levels of study, and more aware of its acceptance on mass media and fashion shows for love of beads concerning culture, value and significance.
\end{abstract}

Keywords: acceptance, beaded jewellery, empowerment, entrepreneurship, female, perception

\begin{abstract}
Abstrak
Studi ini mengukur persepsi penerimaan kaum perempuan Nigeria terhadap program pemberdayaan perhiasan manik-manik untuk pengembangan kewirausahaan. Sebanyak empat buah pertanyaan penelitian dengan dua buah hipotesis dirumuskan dan diuji. Penelitian ini merupakan penelitian deskriptif dengan metode survei. Sebanyak 70 siswa perempuan dari bidang studi Seni Rupa dan Terapan serta 70 perempuan dewasa dari metropolis Ilorin, Nigeria, dilibatkan sebagai sampel yang dipilih secara proporsional. Data diperoleh menggunakan kuesioner terstruktur, terdiri dari enam bagian dan diisi secara mandiri. Data dianalisis menggunakan frekuensi dan persentase, sedangkan hipotesis diuji dengan chi-square dengan tingkat signifikansi 0.05. Studi ini menunjukkan bahwa peserta meyakini manik-manik sebagai bahan utama untuk digunakan; selain itu mereka berpendapat bahwa keterampilan dapat menyita waktu kaum perempuan, namun dapat meningkatkan pendapatan. Produsen dan penjual dapat memeroleh keuntungan yang besar. Keenam sampel mendapatkan penerimaan berdasarkan warna, desain, tekstur dan bentuk. Studi ini menyimpulkan bahwa keterampilan dapat dibutuhkan dan digunakan untuk mengurangi jumlah pengangguran dan waktu luang para kaum perempuan. Beberapa rekomendasi antara lain, keterampilan kerajinan manik-manik perlu
\end{abstract}


dimasukkan ke dalam kurikulum semua tingkat studi. Peningkatan kesadaran dan penerimaan dapat melalui media massa dan fashion show untuk menumbuhkan rasa cinta terhadap manikmanik, budaya, serta nilai signifikansinya.

Kata kunci: kewirausahaan, pemberdayaan, penerimaan, perempuan, perhiasan manik-manik, persepsi,

\section{Introduction}

Beadwork results from appending beads to each other by joining them with a needle and a string or sewing the beads to a bit of material. The bead-making craftsmanship can be earned through formal, casual instruction or apprenticeship (Nguru \& Maina 2020; Wuritta, Dung, \& Musa, 2014). The designing and beading geometric shapes involve mathematics, both in the planning stage and in the making of writing patterns.

Female entrepreneurs are women in business who have recognized the opportunity, developed and grown a business venture successfully. Ali, Zakuan, and Mohammad (2018), asserted that a portion of the pivotal attributes of a business visionary includes: innovativeness, commitment, adaptability, enthusiasm, brilliance and fearlessness. Diandra and Azmy (2020), Ali, Kelley, and Levie (2019) asserted that any business set-up has its vision and one of the business attributes that contribute to a successful outcome. The person that is actively involved is most responsible for receiving the yields of the proceeds. In creating globules as adornments, it is critical to comprehend the design elements and appropriately combine them to guarantee that the completed items are attractive to clients. The basic elements of design include colour, balance, proportion, balance, shape and texture. Innovation is required in the development of these elements. Borowski (2021) asserted that innovation's strategy can be described as the plan of activities to achieve advancement. Any innovation to put in must depend on knowledge and entrepreneurship that involves skill and knowledge (Henning \& Mckelvey 2020). Pisano (2019) indicated that the involvement of innovation in articles to be produced is not easy when the element of design is considered.

Colours can be used to interpret meanings differently. (Ware, 2008). Adebisi and Abdulsalam (2017) asserted that colour furnishes people with the occasion to communicate emotions, make figments in appearance, and can bring excitement to personal life. Different colours can symbolize different moods, feelings, and cultural practices or be a communication tool (Ranjana, 2014).

Balance portrays the dissemination of physical components. It is extremely fundamental and unavoidable when one settles on a basic design. Four kinds of balance are symmetrical, asymmetrical, radial, and crystallographic (Evans \& Thomas 2013). Gatto, Porter, and Selleck (2011) recognized similar kinds of balance. The plans should appear to be identical on the two sides to accomplish balance when delivering beaded gems.

Proportion manages a division of space in the design. The equivalent division of space makes dullness, while the uneven distribution of space turns out to be all the more intriguing. When consolidating accessories and piece of clothing in an outfit, consider their proportions. Think about the length of the bead corresponding to the length of the piece of clothing to the entire outfit on the wearer. Beningfield (2020) asserted that 
appropriate calculation in proportion, balance and harmony bring the beauty of jewellery produced.

Emphasis makes certain items stick out and along these lines pull in more consideration (Evans \& Thomas, 2013). It is a convergence of enthusiasm for a specific piece of the region of a plan. One section is more observable than the others. Emphasis is the focal point of enthusiasm for an outfit. It is the point of convergence that pulls in the eye first. Without the point of convergence of intrigue, an article looks unplanned and tedious.

Texture alludes to the nature of an items' surface, and it could be, rough or patterned. It is the way the bead texture feels and looks. It portrays the nature of the bead materials. It influences how contours look on individuals and harsher the texture, the blunter the colour, and the smoother the colour, the more brilliant the colour.

Shape refers to the two-dimensional object made by lines and icon be largely categorized into two. Mathematical shapes are squares or circles, while organic shapes are irregular shapes. A shape is an enclosed area. State of an outfit is the layout when seen from a good way or in a shadow. A series of lines of different direction defines shape or pattern in relation to square, rectangle, circle and cube (Tomitta 2015; Nelson \& Stolterman, 2012).

The problem observed among some female graduates in the metropolis is their preoccupation with searching for white-collar jobs which is usually nonexistent. This group consist of housewives and unskilled females that are idle and can be empowered with bead making for entrepreneurial development. They can be trained in the art of beaded jewellery making such as rings, bags, belts, sandals, necklaces and bracelets.

Therefore, considering this study's problem statement, four research questions were stated to seek answers to the following: 1) What are the participants' demographic characteristics that assessed the beaded jewellery?; 2) What are the participant's perception of materials used to make beaded jewellery empowerment for entrepreneurial development?; 3) What is the perception of participants on the beaded jewellery empowerment for entrepreneurial development?; 4) What is the perception of participants on the acceptability of beaded jewellery based on colour, balance, design, texture and shape?

Two null research hypotheses were formulated and tested at 0.05 level of significance. They are: $\mathrm{HO}_{1}$ There was no significant relationship between the materials used for making beaded jewellery empowerment and entrepreneurial development. $\mathrm{HO}_{2}$ There was no significant relationship between the acceptance of beaded jewellery empowerment based on design, colour, texture, shape and overall acceptability for entrepreneurial development. Significantly, the findings may be beneficial to counsellors, artists, educationists, cultural institutions, and tourists, ministry of arts and culture, jewellers, unskilled, underemployed adults, the general public and for reference materials.

\section{Literature Review}

Ndofirepi (2020) indicated that entrepreneurship is central to economic development, employment creation, and improvement of people's standards of life in a different community. The continuous improvement of entrepreneurship education takes place if educators understand the implications of entrepreneurship training. According to Ratten and Jones (2020), entrepreneurship offers society the art to move forward 
based on innovation and futuristic thinking. It also equips all that required to discover new opportunities and become competent. Beynon, Jones, Pickernell and Huang (2020) asserted that the knowledge's effectiveness will be determined through networking and interaction with the community. Fejes, Mylund, and Wallin (2019) explained that there is more global acknowledgement on having knowledge areas that will improve the lives of as many involved. Hoarau-Heemstra \& Eide (2019) opined entrepreneurship education to be a global phenomenon that the society needs to possess the knowledge area on the existing business, utilize it and find a new way to assist in building and complementing the processes to achieve desired goals.

According to Rico, Camara, and LIamazare (2015) and Ogundele, Oparinde, and Moronfoye (2013) found out in entrepreneurship education that both entrepreneurs and teachers must involve in training on how to manage a given venture. According to Garcia, Ward, Hernandez, and Florez (2017), entrepreneurship education is creating a thematic programme that can be focused on sectors, industries, or a particular technology. Fayolle (2013) opined that entrepreneurship education is important to target educational efforts in practice. Therefore, entrepreneurship education will assist students in developing the needed skills and expertise towards leveraging on entrepreneurship as a means of making a living and contributing to the country's economic growth. Acquiring beadwork entrepreneurial education might be a good venture since individuals appreciate beads for adornments and decorations.

Nowadays, women adorn themselves with assortments of beautiful beaded accessories made of manufactured beads of various sizes, shapes, and patterns. Articles such as; satchels, handset pockets, bangles, hoops, neckbands, crowns, belts, rings, play toys, wristwatches, mats, blossom jars, handbags, shoes, tops can be produced from beads. Emily (2012) opined that the present beads, which assume a multifaceted job in current style can be generally utilized in types of accessories, arm ornaments, studs, waistbands and sandals. Beadwork magazine (2021) identified inspired designs like unity collar, beaded rapes, shining stars, ornaments, Meredith steals while Fababellela (2016), asserted the type of bead that is a strand of machined and polished amberyellow bead from small to a large size. This is found in the stalls of African beads sellers as well as online stores. As indicated by Adiji (2018), beads are likewise utilized for supplications (rosary bead), hostile to strain gadgets (curry decorations), money (Aggrey beads), gumming, and enhancement (around the globe). Ibebabuchi (2012) revealed that terra-cotta figures from Nok culture that gave proof of the earliest civilization in Nigeria showed that people wore strings of stone beads around the neck, wrist, and lower leg. Agyei, Adu-Agyem, and Steiner (2012) see jewellery-making as a specialty as old as humankind itself. Since our progenitors made their homes in caverns, individuals have made and worn body ornaments. Splendor (2014) explained that one of the most lucrative cottage businesses to begin with extremely low capitals is beaded jewellery making. The individual can master this craft and be helpful during relaxation time or connect on it as a full-time venture to earn some income. This individual involves in entrepreneurship and thus becomes an entrepreneur.

Significantly, there was no difference between the materials used for making beaded jewellery and entrepreneurial development. This implies that both materials and trainers are available. Information will flow adequately and competency might be acquired. Accessories play important role in the outlook of a lady. It is used to enhance personal appearance, however, if it is not selected well and used correctly, these items can mar the dressing and the total appearance of the wearer. Accessories should be 
selected to suit various figure types, complexion and occasions (Foster 2014). There was no significant relationship among the acceptance of beaded jewellery empowerment based on design colour, textile, shape, and overall acceptability for entrepreneurial development.

\section{Methods}

\section{Participants}

The study adopted an experimental research design. It was conducted through January $24^{\text {th }}$ to February $5^{\text {th }}$ 2019. Assorted beads, fishing line, Buckles, Hooks, Stopper, Cutter and Plier were purchased from Comfort Nigeria Enterprise, Oko -Erin Junction, Upper Taiwo Road Market, Ilorin, Nigeria. The making of the jewellery was done in Clothing and Textiles Laboratory of the Department of Home Economics and Food Science, University of Ilorin, Nigeria. The procedures for the production of beaded articles are illustrated thus:

Table 1 Details of materials and quantities for beaded Jewellery (necklace and earring)

\begin{tabular}{lc}
\hline Materials & Quantities \\
\hline Glass beads & $1 \mathrm{~kg}$ \\
Fishing line & $0.2 \mathrm{~m}$ \\
Earring hooks & 0.5 \\
Pliers/Scissors & $1 \mathrm{pc}$ \\
\hline
\end{tabular}

Procedures for the production of beaded jewellery (necklace)

1. Cut out the fishing line and side one bead.

2. Put three inside and cross with one

3. Temporarily close off one end of the beading wire

4. String the entire measured bead.

5. Run the wire back through the bead in the opposite direction.

6. Add hook and stopper.

7. Ready for use.

Procedures for the production of beaded jewellery (earring)

1. Insert bead inside fishing line

2. Insert another one bead inside the left-hand side.

3. Insert three beads inside the right-hand side.

4. Interlock with one bead.

5. Repeat the above steps four times

6. Pass one glass bead and bead underneath

7. Interlock and pass the fishing line and tie.

8. Add the hook and ready for use.

Table 2 Details of materials and quantities for beaded jewellery (belt)

\begin{tabular}{lr} 
Materials & Quantities \\
\hline Beads & $1 \mathrm{~kg}$ \\
Fishing & $0.5 \mathrm{~cm}$ \\
Cutter & $1 \mathrm{pcs}$ \\
Buckles & $2 \mathrm{pcs}$ \\
\hline
\end{tabular}


Procedures for the production of beaded jewellery (belt)

1. Cut fishing line

2. Insert three beads

3. Interlock using one bead to form a circle of three balls.

4. Insert two beads on the right side, one bead on the left side, interlock with one bead out of the two

5. Repeat steps

6. Insert three beads and interlock with one

7. Pass the fishing line in the next available bead

8. Repeat the process to form its width and fix the buckle.

9. Insert the fishing line tightly.

Table 3 Details of materials and quantities for beaded jewellery (bag)

\begin{tabular}{lr}
\hline Materials & Quantities \\
\hline Sound bead & $500 \mathrm{~g}$ \\
Plastic bead & $1.5 \mathrm{~kg}$ \\
Fishing line & $0.5 \mathrm{~cm}$ \\
Cutter & $1 \mathrm{pc}$ \\
\hline
\end{tabular}

Procedures for the production of a beaded bag

1. Cut fishing line

2. Cross the fishing line repeatedly on six pearls

3. Repeat the process for nine lines

4. Repeat until you arrived at the desired length.

5. Prepare the handle to the desired length follows procedures 1 to 2 .

6. Join together and attach the zip.

7. Attach handles.

Table 4 Detail of materials used and quantities of beaded jewellery (sandal)

\begin{tabular}{lr}
\hline Materials & Quantities \\
\hline Soles & 1 pair \\
Bead & $1 \mathrm{~kg}$ \\
Fishing line & $0.6 \mathrm{~cm}$ \\
Insoles material & $36 \mathrm{~cm}$ \\
Buckles & 1 pair \\
Scissors & 1 piece \\
Shoe glue and brush & 1 piece \\
\hline
\end{tabular}

Procedures for the production of beaded jewellery (sandals)

1. Start by making a bead string

2. Pass three beads inside the fishnet and interlock with one

3. Pair the fishing line into two and put two beads at one side and one at the other side.

4. Continue the procedures until you get the length of the desired foot.

5. Shaping the sole and the inner.

6. Cut the insole to the desired size and shape.

7. Apply glue to both and allow to dry little

8. Mark where you want to place the head you have done on the sole

9. Glue it on the sole, punch a small hole and join the buckle to it.

10. Clean and ready for use. 
The beaded pieces of jewellery: belt, sandal, earring, necklace, and bag were produced and displayed in the school pavilion for the participants to perceive if the articles were worthy acceptance for income generation venture. 70 selected students from Fine and Applied Arts, College of Education, Ilorin, Nigeria and 70 women from Ilorin metropolis, Nigeria were selected based on the needy and less privileged program available in the community study was carried out. Participants assessed the sampled jewellery due to their knowledge of designs, texture and colours during their studies and the women who appreciate fashion in the study area. (See pictures on the appendix). A proportional sampling technique was used to select 140 participants for the study. 20 participants were used for the pilot study only (they are excluded from the main survey), while 120 were used for the field survey. Two research assistants were involved in the administration of the questionnaires. Only 90 copies out of 120 copies of the questionnaires were used without mutilation.

\section{Measurement}

The instrument used to seek information from the participants were questionnaires and scorecards. The questionnaire was of three sections. Section A: sought information on the demographic characteristics of the participants. The variables used are age, marital status, religion, educational background, occupation, and income/allowance. Section B contained types of beads used in making the sampled jewellery while section $C$ was based on the statements for participants' perception of this beaded jewellery for income generation. Sections A and B were measured on frequencies and percentages, while section $\mathrm{C}$ was measured based on the 5-Likert scale of strongly agreed (SA/5), agreed (A/4), undecided (UD/3), strongly agreed (SD/2), and disagreed (D/1). The decision rule is 3.00. The scorecard contained participants' perception on coded sampled based on design, texture, color, shape, and overall acceptability. The six coded samples are: 1) $\mathrm{BNK}=$ sandal 2) $\mathrm{BER}=$ necklace, 3) $\mathrm{BRC}=$ earring, 4) $\mathrm{BBG}=$ bracelet 5) $\mathrm{BLT}=$ belt 6$) \mathrm{BS}=$ bag. The scorecard of 7- hedonic scale: Likely Extremely (7), Like Moderately (6), Like Slightly (5), Dislike Extremely (4), Dislike Moderately (3), Dislike (2) and Undecided (1) were used to the sought opinion of participants on self-made coded samples. The decision rule is 4.00.

\section{An Operational Definition of Variables}

The questionnaire is a set of printed or written questions with a choice of answers devised for a survey or statistical study. A scorecard is a statistical record used to measure an individual's progress toward a particular goal, and it is used to measure and provide feedback of the activity that performed. Age is a number, the time that a person has lived. Marital status is it indicates an individual relationship. An individual can be single, married, widowed, divorced or separated. Religion is the belief of worship or derivation of an individual relationship with God or god. Educational background it is the training that an individual had received from childhood to the present stage. The individual had attained it could be formal or informal. Income is the money individual receives on a regular time or basis. Jewellery is a decorative items won by an individual for adornment. This could be earring, necklace, prudent, bag, bracelets. Bead is a small round object gathered together in a string mostly for adornment and other purposes like prayer.

Female: Biological sex or the feminine character that an individual possesses, it denotes the gender that can bear offspring. 
Empowerment: It is the process an individual undergoes to become stronger and more confident in controlling one's life and claiming one's rights.it may involve skill individual possess to earn a living that brings about a wellbeing of an individual.

\section{Analysis}

Data were collected in the form of primary data. The data were obtained by filling questionnaire and scorecard that sought information on demographic characteristics of the participants that assessed the beaded jewellery empowerment, materials used in making beaded jewellery empowerment and acceptability of beaded jewellery based on colour, balance, design, texture and shape.

Statistical Package for the Social Sciences (SPSS 21 windows) was used to analyze the data. Editing, coding, entry, scoring, and analysis were used for processing the data. Analyzing the actual visual design process could bring new knowledge to the field and help designers make optimal design judgments. Descriptive statistics of frequency counts, percentages, mean and standard deviation were used to achieve the objectives while the null hypotheses were tested using statistical package for social science version 26 .

\section{Findings}

\section{Nigerian Females Demographic Characteristics}

The findings describe the demographic characteristics of the participants in Ilorin, Nigeria. The data on age distribution shows that majority: $55(61.1 \%)$ participants were between the ages of 21-30. This is a prime stage in a man's life that the psychomotor domains are very active. Involvement in beaded jewellery empowerment will be additional wings to them. The educational background shows that the majority: 29 (32.2\%) participants had no formal education. Majority: 51 (56.7\%) participants are married. This implies that this group needs additional income to argument the needs of the family. The involvement in beaded jewellery empowerment might make the family free from the economic embarrassment and live a better life of fulfilment. $70(70.8 \%)$ of the participants practised Christianity and $29(23.22 \%)$ participants are students. This is because capacity-building programs are carried out in various churches in the environment. They are aware of its importance. This implies that the participants are not ready to battle with Nigeria's unemployment.

\section{Perception of Nigerian Females on the Acceptability of Materials Used in Making Beaded Jewellery}

Table 6 indicates the materials used in making beaded jewellery for entrepreneurial development. The participants agreed on all the 10 items stated. They indicated that beads are the major materials needed in the production of beaded jewellery with a mean score of 4.39. Strings, stoppers, hooks, pairs of scissors, pliers, and needles should be in good condition, durable, affordable, and easily available. The availability of materials will prompt the beaded jewellery to be available on the scheduled time without any disappointment. Also, the materials should be appealing. The means of all the items are more than 3.00. Above all, the grand mean of 4.17 is also greater than the decision rule of 3.00. The implies that certain materials are needed 
specifically for the production of beaded jewellery for the articles to come out attractive and to last long for stakeholders to like and appreciate the works of arts.

Table 6 Materials used for making beaded jewellery by the participants

\begin{tabular}{lrrr}
\hline Statements & $\overline{\boldsymbol{X}}$ & SD & Remarks \\
\hline Beads are the major material needed in the production of beaded & 4.39 & 1.16 & Agree \\
jewellery. & & & \\
Strings are used for joining beads together during the production. & 4.47 & 0.95 & Agree \\
Stoppers and hooks can be used during production. & 4.54 & 0.95 & Agree \\
Buckles can be used as one of the accessories. & 4.28 & 1.13 & Agree \\
Pairs of scissors are needed for cutting strings. & 4.30 & 1.04 & Agree \\
Pliers, needle or pin are needed for the production of beaded & 4.06 & 1.31 & Agree \\
jewellery. & & & \\
All the materials needed for production must be durable. & 3.94 & 1.27 & Agree \\
All the materials needed must be affordable. & 4.06 & 1.17 & Agree \\
All the materials needed must be easily available. & 3.96 & 1.29 & Agree \\
The materials should be appealing. & 3.69 & 1.22 & Agree \\
Grand Mean & 4.17 & & Agree \\
\hline
\end{tabular}

*Note: Field Survey (2020)

\section{Perception of Nigerian Females on Beaded Jewellery Empowerment for Entrepreneurial Development}

Table 7 indicates the perception of participants on beaded jewellery empowerment for entrepreneurial development. There are 17 item-statements, $82 \%$ of the participants strongly agreed and agreed that beaded jewellery occupies makers time. This implies that $90 \%$ of the participants strongly agreed and agreed that the article can be sold to generate income. This means that there will not be any reason for anyone that engages in the production and sales to experience financial lack. $77.40 \%$ strongly agreed that the participants believe that anyone who engages on beaded jewellery can realize profits that will be better than idle, lazy and jobless. $87 \%$ of participants strongly agreed that beaded jewellery can be used for ceremonies. On the other side, $87.67 \%$ strongly disagreed and disagreed to the statement of beaded jewellery waste time while $20.00 \%$ of participants strongly disagreed and disagreed that beaded jewellery is an old fashion.

Table 7 Beaded jewellery empowerment for entrepreneurial development

\begin{tabular}{|c|c|c|c|c|c|}
\hline Statements & $\begin{array}{l}\text { SA } \\
(\%)\end{array}$ & $\begin{array}{l}\text { A } \\
(\%)\end{array}$ & $\begin{array}{l}\text { UD } \\
(\%)\end{array}$ & $\begin{array}{l}\text { SD } \\
(\%)\end{array}$ & $\begin{array}{l}\text { D } \\
(\%)\end{array}$ \\
\hline Making of beaded jewellery occupies the makers time. & 62.20 & 20.00 & 4.40 & 7.80 & 5.60 \\
\hline Beaded jewellery can be sold to generate income. & 74.40 & 15.60 & 6.70 & 1.10 & 2.20 \\
\hline Beaded jewellery cannot be used to generate income. & 2.33 & 1.10 & 8.90 & 28.77 & 58.90 \\
\hline $\begin{array}{l}\text { Profits can be realized from the sales of beaded } \\
\text { jewellery. }\end{array}$ & 50.00 & 27.80 & 11.10 & 6.70 & 4.40 \\
\hline $\begin{array}{l}\text { Profits realized from beaded jewellery are substantial } \\
\text { to the producers }\end{array}$ & 42.20 & 30.00 & 12.20 & 10.00 & 5.60 \\
\hline $\begin{array}{l}\text { Profits realized from beaded jewellery are not } \\
\text { substantial to the producers and the sellers }\end{array}$ & 70.00 & 16.70 & 5.60 & 4.40 & 3.30 \\
\hline $\begin{array}{l}\text { Profits realized are used to take care of the needs of the } \\
\text { producers or sellers }\end{array}$ & 13.30 & 5.60 & 21.10 & 23.50 & 36.70 \\
\hline $\begin{array}{l}\text { Profits realized from beaded jewellery is better than } \\
\text { being idle, lazy or jobless. }\end{array}$ & 70.00 & 16.70 & 5.60 & 5.60 & 2.20 \\
\hline
\end{tabular}




\begin{tabular}{|c|c|c|c|c|c|}
\hline Statements & $\begin{array}{l}\text { SA } \\
(\%)\end{array}$ & $\begin{array}{l}\text { A } \\
(\%)\end{array}$ & $\begin{array}{l}\text { UD } \\
(\%)\end{array}$ & $\begin{array}{l}\text { SD } \\
(\%)\end{array}$ & $\begin{array}{l}\text { D } \\
(\%)\end{array}$ \\
\hline Production of beaded jewellery is a waste of time & 10.00 & 8.90 & 22.20 & 15.60 & 43.30 \\
\hline Beaded jewellery is old fashion. & 14.00 & 15.60 & 20.00 & 12.20 & 12.20 \\
\hline Beaded jewellery can only be bought by elderly people & 11.10 & 24.40 & 22.20 & 15.50 & 26.70 \\
\hline Beaded jewellery can only be bought by Illiterates & 11.10 & 28.90 & 26.70 & 10.00 & 23.00 \\
\hline Beaded jewellery can be bought by anyone & 46.70 & 15.60 & 26.60 & 2.20 & 8.90 \\
\hline Beaded jewellery can be utilized by anyone & 25.60 & 18.90 & 35.60 & 17.80 & 2.20 \\
\hline Beaded jewellery can be utilized as gifts & 35.50 & 11.10 & 23.30 & 21.10 & 8.90 \\
\hline Beaded jewellery can only be used for ceremonies & 70.00 & 17.80 & 5.60 & 4.40 & 2.20 \\
\hline $\begin{array}{l}\text { Beaded jewellery can be used at any time for any } \\
\text { purpose. }\end{array}$ & 32.20 & 24.40 & 24.40 & 14.40 & 4.40 \\
\hline
\end{tabular}

Perception of Participants on Coded Sampled for Entrepreneurial Development

Table 8.1 indicates the perception of participants on sampled beaded sandal coded BNK. The sampled sandal mean scores based on design is 5.03, the texture is 5.11, colour is 4.90, the shape is 5.23 and overall acceptability is 5.34. The decision rule is 4 . 00. All the mean scores are greater than 4.00. This implies that the participants perceived the acceptance of beaded sandal for entrepreneurial development. This might be because the participants appreciate the uniqueness of the bag. The attraction might urge some females to purchase it and even give it out as a gift. This is because the participants appreciate the works of arts in terms of design, texture, shape and overall acceptability. Each of them is presented in various ways to produce a wide of varieties of interesting effects. The sandal design is extremely like with $16.7 \%$, texture $3.3 \%$, color $11.1 \%$, shape $24 \%$, and the overall acceptability is $15.6 \%$. The colours. The pink and white makes the sandals look welcoming and the user might look more cheerful and pleasing. The color also might prompt an individual to like extremely to purchase for one's utilization or give out as a gift.

Table 8.1 Coded sampled sandal (BNK) for entrepreneurial development

$\begin{array}{lrrrrrrrr}\begin{array}{l}\text { Coded } \\ \text { Sample } \\ \text { (BNK) }\end{array} & \text { LE } & \mathbf{L M} & \mathbf{L S} & \mathbf{D E} & \mathbf{D M} & \mathbf{D} & \text { UD } & \overline{\boldsymbol{x}} \\ \text { Mean }\end{array}$

*Note: field survey (2020); LE/7=Like Extremely, LM/6=Like Moderately, LS/5=Like Slightly, DE/4=Dislike Extremely, DM/3=Dislike Moderately, D/2=Dislike, UD/1=Undecided

Table 8.2 shows the perception of participants on sampled beaded necklace coded BER. The sampled necklace mean scores based on design are 5.44, the texture is 5.32, the color is 5.18, and the shape is 4.94 while overall acceptability is 5.43 . The mean scores of the data are greater than 4.00. This means that the participants perceived the 
acceptance of a necklace for entrepreneurial development. This is because the indigenous people are happy with the shape and the adornment function it performs. Most participants moderately like a beaded necklace.

Table 8.2 Sampled coded beaded necklace (BER) for entrepreneurial development

\begin{tabular}{|c|c|c|c|c|c|c|c|c|}
\hline $\begin{array}{l}\text { Coded } \\
\text { Sampled }\end{array}$ & $\begin{array}{r}\text { LE } \\
7\end{array}$ & $\begin{array}{r}\text { LM } \\
6\end{array}$ & $\begin{array}{r}\mathrm{LS} \\
5\end{array}$ & $\begin{array}{r}\text { DE } \\
4\end{array}$ & $\begin{array}{r}\text { DM } \\
3\end{array}$ & $\begin{array}{r}\text { D } \\
2\end{array}$ & $\begin{array}{r}\text { UD } \\
1\end{array}$ & $\begin{array}{r}\bar{X} \\
\text { Mean }\end{array}$ \\
\hline (BER) & & & & & & & & \\
\hline Design & $18(20.0)$ & $32(35.6)$ & $26(28.9)$ & $8(8.9)$ & $2(2.2)$ & 0 & $4(4.4)$ & 5.44 \\
\hline Texture & $18(20.0)$ & $22(24.4)$ & $33(36.7)$ & $11(12.2)$ & $2(2.2)$ & $2(2.2)$ & $2(2.2)$ & 5.32 \\
\hline Colour & $15(16.7)$ & $23(25.6)$ & $26(28.9)$ & $18(20.0)$ & $5(5.6)$ & $3(3.3)$ & 0 & 5.18 \\
\hline Shape & $13(14.4)$ & $29(32.2)$ & $19(21.1)$ & $13(14.4)$ & $5(5.6)$ & $7(7.8)$ & $3(3.3)$ & 4.94 \\
\hline $\begin{array}{l}\text { Overall } \\
\text { acceptability }\end{array}$ & $14(15.6)$ & $34(37.8)$ & $28(31.1)$ & $10(11.1)$ & $1(1.1)$ & $1(1.1)$ & $2(2.2)$ & 5.43 \\
\hline
\end{tabular}

Table 8.3 reveals the perception of participants on sampled beaded earring coded BRC for entrepreneurial development. The sampled earring mean scores based on design is 5.43, the texture is 4.00 . The shape is 5.58 while overall acceptability is 5.5. The designing of the article brings a transformation of ideas that reflects the interest of the designer. This implies that the earring is moderately liked. The imaginary of putting beads together and presenting it in what is in the designer's mind for others to see make it more liked.

Table 8.3 Sampled coded beaded earring (BRC) for entrepreneurial development

\begin{tabular}{lrrrrrrrr}
\hline $\begin{array}{l}\text { Coded } \\
\text { Sample } \\
\text { (BBG) }\end{array}$ & LE & $\mathbf{L M}$ & $\mathbf{L S}$ & $\mathbf{D E}$ & $\mathbf{D M}$ & $\mathbf{D}$ & UD & $\begin{array}{r}\overline{\boldsymbol{X}} \\
\text { Mean }\end{array}$ \\
\hline Design & $\mathbf{7}$ & $\mathbf{6}$ & $\mathbf{5}$ & $\mathbf{4}$ & $\mathbf{3}$ & $\mathbf{2}$ & $\mathbf{1}$ & \\
Texture & & & & & & & & \\
Colour & $18(20.0)$ & $34(37.8)$ & $23(25.6)$ & $8(8.9)$ & $1(1.1)$ & $3(3.3)$ & $3(3.3)$ & 5.43 \\
Shape & $10(11.1)$ & $16(17.8)$ & $18(20.0)$ & $20(22.2)$ & $9(10.0)$ & $7(7.8)$ & $10(11.1)$ & 4.30 \\
Overall & $15(16.7)$ & $27(30.0)$ & $19(21.1)$ & $15(16.7)$ & $5(5.6)$ & $1(1.1)$ & $7(7.8)$ & 5.58 \\
acceptability & $19(21.1)$ & $31(34.4)$ & $18(20.0)$ & $13(14.4)$ & $3(3.3)$ & $3(3.3)$ & $3(3.3)$ & 5.52 \\
\hline Note: Field Survey (2020); LE/7=Like Extremely, LM/6=Like Moderately, LS/5=Like Slightly, DE/4=Dislike \\
Extremely, DM/3=Dislike Moderately, D/2=Dislike, UD/1=Undecided
\end{tabular}

Table 8.4 shows that the participants perceived the sampled beaded bracelet coded BBG. The sampled bracelet mean scores on design are 5.85, the texture is 5.44, the color is 5.67, the shape is 5.12 and overall acceptability is 5.91. This bracelet is extremely liked with design $46.7 \%$, texture $32.2 \%$, colour $45.6 \%$, shape $52.2 \%$ and overall acceptability $57.8 \%$. The combination of these traits in the production is important in achieving a well-dressed appearance. Colour may be used to highlight best body features that will make the wearer feel happy, cheerful, healthy and full of energy. 
Table 8.4 Sampled coded beaded bracelet (BBG) for entrepreneurial development

\begin{tabular}{lrrrrrrrr}
\hline $\begin{array}{l}\text { Coded } \\
\text { Sample } \\
\text { (BBG) }\end{array}$ & $\mathbf{L E}$ & $\mathbf{L M}$ & $\mathbf{L S}$ & $\mathbf{D E}$ & $\mathbf{D M}$ & $\mathbf{D}$ & UD & $\begin{array}{r}\overline{\boldsymbol{X}} \\
\text { Mean }\end{array}$ \\
\hline Design & $\mathbf{7}$ & $\mathbf{6}$ & $\mathbf{5}$ & $\mathbf{4}$ & $\mathbf{3}$ & $\mathbf{2}$ & $\mathbf{1}$ & \\
Texture & $42(46.7)$ & $17(18.9)$ & $13(14.4)$ & $9(10.0)$ & $5(5.6)$ & $3(3.3)$ & 0 & 5.85 \\
Colour & $29(32.2)$ & $24(26.7)$ & $12(13.3)$ & $16(17.8)$ & $4(4.4)$ & $2(2.2)$ & $3(3.3)$ & 5.44 \\
Shape & $41(45.6)$ & $15(16.7)$ & $15(16.7)$ & $9(10.0)$ & $3(3.3)$ & $2(2.2)$ & $4(4.4)$ & 5.67 \\
Overall & $47(52.2)$ & $13(14.4)$ & $12(13.3)$ & $10(11.1)$ & $3(3.3)$ & $3(3.3)$ & $2(2.2)$ & 5.82 \\
acceptability & $52(57.8)$ & $9(10.0)$ & $15(16.7)$ & $6(6.7)$ & $3(3.3)$ & $1(1.1)$ & $4(4.4)$ & 5.91 \\
$*$ Note: field survey (2020); LE/7=Like Extremely, LM/6=Like Moderately, LS/5=Like Slightly, DE/4=Dislike \\
Extremely, DM/3=Dislike Moderately, D/2=Dislike, UD/1=Undecided
\end{tabular}

Table 8.5 indicates the participant's perception of sampled beaded belt coded. The sampled beaded belt mean scores based on design is 5.78, the texture is 5.22, colour is 5.24 , the shape is 5.41 and overall acceptability is 5.66 . The data reveals that like extremely: design $24.4 \%$, texture $26.7 \%$, colour $28.9 \%$, shape $25.6 \%$ and overall acceptance $23.3 \%$. This implies that the participants appreciate the beauty of craft in a beaded belt.

Table 8.5 Sampled coded beaded belt (BLT) for entrepreneurial development

\begin{tabular}{|c|c|c|c|c|c|c|c|c|}
\hline $\begin{array}{l}\text { Coded Sample } \\
\text { (BLT) }\end{array}$ & $\begin{array}{r}\text { LE } \\
7\end{array}$ & $\begin{array}{r}\text { LM } \\
6\end{array}$ & $\begin{array}{r}\mathbf{L S} \\
\mathbf{5}\end{array}$ & $\begin{array}{r}\text { DE } \\
4\end{array}$ & $\begin{array}{r}\text { DM } \\
3\end{array}$ & $\begin{array}{l}\text { D } \\
2\end{array}$ & $\begin{array}{r}\text { UD } \\
1\end{array}$ & $\begin{array}{r}\bar{X} \\
\text { Mean }\end{array}$ \\
\hline Design & $22(24.4)$ & $39(43.3)$ & $22(24.4)$ & $5(5.6)$ & 0 & 0 & $2(2.2)$ & 5.78 \\
\hline Texture & 24(26.7) & $16(17.8)$ & $25(27.8)$ & $16(17.8)$ & $2(2.2)$ & $4(4.4)$ & $3(3.3)$ & 5.22 \\
\hline Colour & $26(28.9)$ & 17(18.9) & 17(18.9) & $21(23.3)$ & $5(5.6)$ & 0 & $4(4.4)$ & 5.24 \\
\hline Shape & $23(25.6)$ & $33(36.7)$ & $11(12.2)$ & $15(16.7)$ & $2(2.2)$ & $1(1.1)$ & $5(5.6)$ & 5.41 \\
\hline Overall & $21(23.3)$ & $39(43.3)$ & $18(20.0)$ & $6(6.7)$ & $4(4.4)$ & 0 & $2(2.2)$ & 5.66 \\
\hline
\end{tabular}

*Note: field survey (2020); LE/7=Like Extremely, LM/6=Like Moderately, LS/5=Like Slightly, DE/4=Dislike Extremely, DM/3=Dislike Moderately, D/2=Dislike, UD/1=Undecided

Table 8.6 reveals the perception of participants on sampled beaded bag coded BS. The sampled bag mean scores based on design is 6.20 , the texture is 5.54, colour is 5.67, the shape is 5.83 and overall acceptability is 6.02 . The sampled bag is the most acceptable based on the highest mean scores. The attractive shape of the beaded bag makes participants extremely liked the bag.

Table 8.6 Sampled coded beaded bag (BS) for entrepreneurial development

\begin{tabular}{|c|c|c|c|c|c|c|c|c|}
\hline Coded & LE & LM & LS & $\mathrm{DE}$ & $\mathrm{DM}$ & $\mathrm{D}$ & UD & $\bar{X}$ \\
\hline $\begin{array}{l}\text { sample } \\
\text { (BS) }\end{array}$ & 7 & 6 & 5 & 4 & 3 & 2 & 1 & Mean \\
\hline Design & $61(67.8)$ & $11(12.2)$ & $7(7.8)$ & $5(5.6)$ & $2(6.6)$ & 0 & $4(4.4)$ & 6.20 \\
\hline Texture & $36(40.0)$ & $22(24.4)$ & $10(11.1)$ & $10(11.1)$ & $6(6.7)$ & $1(1.1)$ & $5(5.6)$ & 5.54 \\
\hline Colour & $32(35.6)$ & $25(27.8)$ & 11(12.2) & 11(12.2) & $6(6.7)$ & $2(2.2)$ & 0 & 5.67 \\
\hline Shape & $44(48.9)$ & $13(14.4)$ & $8(8.9)$ & $8(8.9)$ & $2(2.2)$ & $2(2.2)$ & $2(2.2)$ & 5.83 \\
\hline $\begin{array}{l}\text { Overall } \\
\text { acceptability }\end{array}$ & $50(55.6)$ & $19(21.1)$ & $7(7.8)$ & $7(7.8)$ & $2(2.2)$ & $2(2.2)$ & $2(2.2)$ & 6.02 \\
\hline
\end{tabular}

The process involved in the production is very interesting. Therefore, much attention is given and thus bring improvement in the quality of work. The colours pink and white make the shape of the bag come out fine. It is possible to use this bag for 
different occasions. The design $67.8 \%$, texture $40.0 \%$, colour $35.6 \%$, shape $48.9 \%$ and overall acceptability $55.6 \%$. The harmonization of the traits make the bag to be attractive and extremely liked.

\section{Materials Used for Beaded Jewellery Empowerment for Entrepreneurial Development}

Table 9 indicates the calculated chi-square of 24.32 is greater than 25.00 which is the critical value, it, therefore, means that the materials used for beaded jewellery produced have any relationship with female empowerment. The data shows that, when adequate materials are ready, the participants too were ready to acquire the skill. The readiness of learner is important coupled with the materials that the learner will use to carry out the designated assignment at a given time.

Table 9 Analysis of materials used for beaded jewellery empowerment for entrepreneurial development

$\begin{array}{llllllllll}\text { Variables } & \mathbf{N} & \overline{\mathbf{x}} & \text { SD } & \text { SL } & \text { DF } & \mathbf{X}^{2} & \begin{array}{r}\text { Cr. } \\ \text { Value }\end{array} & \text { Sig } & \text { Remark }\end{array}$

Materials used for beaded $90 \quad 60.45 \quad 19.52$
jewellery
jewellery

Empowerment for entrepreneurial $90 \quad 41.69 \quad 11.41$ development

*Note: field survey (2020); N=Number of cases, $\bar{x}=$ mean, $\mathrm{SD}=$ Standard Deviation, $\mathrm{SL}=$ Significance Level, $\mathrm{DF}=$ Degree of freedom.

\section{Perception of Participants on the Overall Acceptability of Beaded Samples for Entrepreneurial Development}

Table 10 shows the overall acceptability of beaded samples by the participants for entrepreneurial development. The data reveals that the participants accepted the six (6) samples: BNK, BER, BRC, BBG, BLT, and BS for female empowerment. The data indicates the mean ranges from 5.03 to 6.02 for the six coded samples. It means of the participants accepted BNK (sandal) based on the following: design (5.03), texture (5.11), colour (4.90), shape (5.23), and overall acceptability (5.34).

Table 10 Mean and Standard Deviation of the Acceptability Level of the Samples

\begin{tabular}{lcccrr}
\hline Sample code & Design & Texture & Colour & Shape & $\begin{array}{r}\text { Overall } \\
\text { acceptability }\end{array}$ \\
\hline BNK & $5.03 \pm 1.51$ & $5.11 \pm 1.50$ & $4.90 \pm 1.62$ & $5.23 \pm 1.46$ & $5.34 \pm 1.46$ \\
BER & $5.44 \pm 1.35$ & $5.32 \pm 1.41$ & $5.18 \pm 1.00$ & $4.94 \pm 1.25$ & $5.43 \pm 1.46$ \\
BRC & $5.43 \pm 1.31$ & $4.96 \pm 1.37$ & $4.30 \pm 1.69$ & $5.58 \pm 1.29$ & $5.52 \pm 1.41$ \\
BLT & $5.78 \pm 1.57$ & $5.22 \pm 1.65$ & $5.24 \pm 1.57$ & $5.41 \pm 1.62$ & $5.66 \pm 1.11$ \\
BS & $6.20 \pm 1.04$ & $5.54 \pm 1.18$ & $5.64 \pm 1.13$ & $5.83 \pm 1.08$ & $6.02 \pm 1.04$ \\
\hline$*$ Note: laboratory survey $(2020) ;$ BNK=sandal, BER=necklace, BRC=ear ring, BBG=bracelet, BLT=belt and BS=bag
\end{tabular}

Means of participants that accepted BER (necklace) include design (5.44), texture (5.32), colour (5.18), shape (4.94), and overall acceptability (5.43). The means of the participants that accepted. BRC (earring) were: design (5.43), texture (4.96), colour (4.30), shape (5.58), while the overall acceptability was 5.52. Also, the means of the participants that accepted BLT (belt) include design (5.78), texture (5.22), colour (5.24), and shape (5.41), while the overall acceptability is 5.66. Also, the means of the 
participants that accepted BS (bag) were: design (6.20), texture (5.44), colour (5.67), and the overall acceptability is 6.02. Therefore, BS (bag) is the most and overall accepted out of the six coded samples. Beaded bag, the extremely liked.

\section{Discussion}

The participants' perception on the self-six produced coded samples revealed that the articles are generally accepted based on the design, texture, colour and shape. According to Pertuz and Perez (2021), innovation should be involved in the production of any products. The most generally accepted among them is the beaded bag. When all these elements are put together creatively and innovatively, the skill can be empowered and utilized to earn income that will improve financial lack and idleness.

The ornament of female adornment can be in the form of an earring, necklace with pendants, bracelets, and clutch bag. This can communicate inner feelings and a sense of style. The participants perceived and accepted that beads are the major materials used in making beaded jewellery. Elnashar (2018) views bead as a form punctured by a hole through it and is composed of multiple through it and is composed of multiple ores, whether natural ore: such as; some fruits, plant seeds deposit, shells, woods, ivory glass, and plastic. Adiji (2018) perceived bead making to be a laborintensive process, and also many of the beads are hand-made. This leads to variability in the appearance of an individual within a single strand. According to Agyei, AduAgyerm, and Steiner (2012), they opined, the materials used depend largely on the availability of new materials and technology of the people. Kankan-Dwumfour (2011) asserted beads are merely part of an assemblage of materials such as twigs, seeds, shell, metal bones, and ceramic wares.

Kay (2013) describes that beads can hold special meanings when carefully, systematically and intentionally selected, express ideas-literally and metaphorically. Gotts (2014) asserted that beads are small and portable objects of potential high value by their nature. They constitute an art form ideally suited for long-distance commerce that can be acceptable to generate income.

Nigeria needs to continue to empower females through the knowledge of entrepreneurial education. The empowerment will enable them to effectively use their psychomotor domain, having an income of their own and possibly own properties. According to Abiodun and Bukki (2018), women have suffered discrimination in many societies, especially in developing countries. Ironically, they bear the major burden of responsibilities for food, produce, and rear children, have little or no access to the means of creating income for themselves. Ali \& Salisu (2019) opined that if you educate, train or empower a man, you empower an individual but if you train a woman, you empower the whole society because women are builders. They are the community organizers, family activists as well as home managers.

Based on females' perception on beaded jewellery for entrepreneurial development, the participants perceived that empowered skills occupy one's time and generate income for the individual. Profits realized from beaded jewellery can be substantial to the producers and sellers. This is in line with Adebisi and Oduneye (2016). They opined that entrepreneurship drives and creates wealth in society by putting together various resources that can benefit customers and anyone that provides 
the innovation. Anyakoha (2015) asserted that entrepreneurship is the ability to seek out investment opportunities, establish and run the business enterprise successfully.

Craftwork is a good venture that can be transferred from one generation to the other. Formal education is not compulsory. A noted example is Nike Okundaye who had no formal education became an expert in Nike Arts Gallery located in Lagos, Abuja and Osogbo, Nigeria (The Guardian, 2015). Craftwork can be inborn and the proceeds of the competency are very encouraging. The study is limited based on the location to Ilorin, Nigeria. Beads are culturally utilized but this generation in Nigeria thinks they should be for the elderly and mature adults.

\section{Conclusion and Recommendations}

\section{Conclusion}

The study established that there are different opinions on beaded jewellery empowerment among the participants. After careful observations and studies, it was established that the participants accepted beaded jewellery as one of the income generation skills that some females can acquire. The skill will prevent idleness and awareness of others. For any individual to be an entrepreneur and be successful, she has to start from somewhere, at least from a little beginning. There is no magic pill that mostly launches an individual out of her cubicle confinement into the free world of entrepreneurship. An entrepreneur needs to be creative, persistent, and innovative. Also, needs to be pleasing to the clients. Entrepreneurial development employs the populace. Individual who engages in something is better than those that are just procrastinating. The person has gained knowledge and experience as she continues on the skill.

\section{Recommendations}

Based on the findings made in this study, it is therefore recommended that 1 . More awareness should be carried out on the utilization of beaded adornments. 2. The bead designers should try to make a good, attractive, and fast decision to combine color, design, texture, and shape to her products to attract buyers. 3. The study of bead crafts should be included in the curriculum for all study levels, especially starting from the senior elementary schools. There is a need for educational programs on bead crafts through the media, symposia, and fashion shows to create the much-needed public awareness on the love of beads in-relation to culture, value, and significance. 4. Training of specialists in bead crafts arts. Bead shows or fashion shows, fashion fairs and exhibition could be organized by bead makers, bead sellers, fashion designers and students' associations in the schools. 5. Establishments of national beads technology centres in the existing area.

\section{Acknowledgement}

The research team has no financial or commercial relations with any organization. It was self-sponsored research. The team acknowledged laboratory technologists and attendants of the department of Home Economics and Food Science, University of Ilorin, Nigeria for making themselves available and assistance in making the laboratory available. Also, the Department of Fine and Applied Arts students, College of Education, Ilorin, Nigeria, and selected women in Ilorin community for taking time to assess the self-produced samples (jewellery) are duly acknowledged. 


\section{References}

Abiodun, O., \& Bukki, A. (2018). Empowering Nigerian women through entrepreneurship education. Empowering Nigerian Women through Entrepreneurship Education. Journal of Business, 7(1), 11-20.

Adebisi, T., \& Abdulsalam, A. (2017). Factors influencing colours in clothing selection. Journal of Asian Regional Association for Home Economics, 24(2), 56-63.

Adebisi, T., \& Oduneye, O. (2016). Influence of entrepreneurship education on textile and clothing designers for economic empowerment in Abeokuta, Ogun State. The Journal entrepreneurship and business management, 2(1), 100-114

Adiji, B. (2018). Use of beads in the contemporary fashion industry of South Western Nigeria. International Journal of African Society, Cultures and Traditions, 6(1), 7-14. ISSN: 2056-5771.

Agyei, I., Adu-Adyem, J., \& Steiner, R. (2012). Exploring traditional glass bead making techniques in jewellery. Journal of Science and Technology, 32(3), 103-112. Doi: $10.4314 /$ just.v32i3.11

Ali, A. M., Zakuan, A. A. U. A., \& Mohammad, B. Z. (2018). Northern Nigerian women participation in trade union movement: Impediments and Solutions. Journal of Humanities and Cultures Studies R\&D, 4(4), 1-12. ISSN: 2490- 4228.

Ali, A., Kelley, D., \& Levier, J. (2019). Market-driven entrepreneurship and institutions. Journal of Business Research, 113, 117-128. Doi: 10.1016/j.jbusres.2019.03.010

Ali, M., \& Salisu, Y. (2019). Women entrepreneurship and empowerment strategy for national development. Journal of Economics, Management and Trade, 22(3), 113. Doi: $10.9734 / J E M T / 2019 / 44828$

Anyakoha, E. (2015). Home management for schools and colleges, Onitsha, Africana first publishers PLC.

Bartelsmon, M., \& Hagasten, E (2019). Productivity technological innovations and broad and connectivity firm-level evidence for ten European countries, Eurasian Economic Review, 9(1), 25-48. Doi: 10.1007/s40821-018-0113-0

Beadwork. (2020, February/March). Fabulous Leather and Lace jewellery making projects digital edition. Retrieved from: https://www.interweave.com/product/beadwork-february-march-2020-digitaledition/

Beningfield, K. (2020). Contemporary geometric beaded jewellery. Journal of Mathematics and the Arts, 14(1-2), 15-18. Doi: 10.1080/17513472.2020.1729455.

Beynon, M. J., Jones, P., Pickernell, D., \& Huang, S. (2020). Growth and innovation of SMEs in local enterprise partnerships regions: A configurational analysis using fsQCA. The International Journal of Entrepreneurship and Innovation, 21(2), 83-100. Doi: 10.1177\%2F1465750319846827

Boon, J., Van der Klink, \& Janssen, J. (2013). Fostering Intrapreneurial Competences of Employees in the Education Sector. International Journal of Training and Development, 17(3), 210-220. Doi: 10.1111/ijtd.12010

Borowski, P. F. (2021). Innovation strategy on the example of companies using bamboo. Journal of Innovation and Entrepreneurship, 10(1), 1-17. Doi: 10.1186/s13731-020-00144-2 
Chawinga, W. D. (2017). Taking social media to a university classroom: teaching and learning using Twitter and blogs. International Journal of Educational Technology in Higher Education, 14(1), 1-19. Doi: 10.1186/s41239-017-0041-6

Diandra, D., \& Azmy, A. (2020). Understanding definition of entrepreneurship. International Journal of Management, Accounting and Economics, 7(5), 235-241. ISSN:2383-2126.

Elnashar, E. A. (2018). A unified fashion technology in trends of Textile Engineering Science, 7000 BG in Egypt. Trends in Textile Engineering and Fashion Technology, 2(1), 1-3.

Emily, G. (2012). Beads: A short history. Retrieved from: http://crystalcure.com/article-bead-history.html

Evans, P., \& Thomas, M. (2013). Exploring the elements of design. Delmar: Cengage Learning.

Falabella, R. (2016). Imitation Amber Beads of Phenolic Resin from the African Trade. Beads: Journal of the Society of Bead Researchers, 28(1), 3-15.

Fayolle, A. (2013). Personal views on the future of entrepreneurship education. Entrepreneurship and Regional Development. 25(7-8), 692-701. Doi: 10.1080/08985626.2013.821318.

Feyes, A. Mylund, M. \& Wallin, J. (2019). How do teachers interpret and transform entrepreneurship education?. Journal of Curriculum Studies, 51(4), 554-566. Doi: 10.1080/00220272.2018.1488998

Foster, P (2014). Clothing and textiles. Ghana: Winmat Publishers Limited.

Garcia, J.C, Ward, A., Hernandez, B., \& Florez, J. (2017). Entrepreneurship Education: State of the Arts. Propositos Represeritaiones, 5(2), 401-473. Doi: http://dx.doi.org/10.20511/pyr2017.v5n2.190

Gatto, J., Porter, A., \& Selleck, J. (2011). Exploring visual design: The elements and principles. Davis Publications.

Gotts, S. (2014). Ghana glass bead making arts in transcultural dialogues. African ART Spring, 47(1), 10-29. Doi: 10.1162/AFAR_a_00119

Henning, M., \& McKelvey, M. (2020). Knowledge, entrepreneurship and regional transformation: Contributing to the Schumpeterian and evolutionary perspective on the relationships between them. Small Business Economics, 54(2), 495-501. Doi: 10.1007/s/1/87-018-0113-0

Hoarau-Heemstra, H., \& Eide, D. (2019). Values and concern: Drivers of innovation in experience-based tourism. Tourism and Hospitality Research, 19(1), 15-26. Doi: $10.1177 / 1467358416683768$

Ibebabuchi, A. (2012). Bead making and ornamentation in Nigeria. International Journal of African Society, Cultures and Traditions. 6, 7-14.

Kankam-Dwumfour, E. (2011). Recycled glass bead production in selected towns in Ashanti (Doctoral dissertation, M. Phil Thesis, KNUST, Kumasi: Department of General Art Studies).

Kay, L. (2013). Bead collage: An arts-based research method. International Journal of Education \& the Arts, 14(3), 1-17. Retrieved from: http://www.ijea.org/v14n3/v14n3.pdf

Ndofirepi, T. M. (2020). Relationship between entrepreneurship education and entrepreneurial goal intentions: psychological traits as mediators. Journal of Innovation and Entrepreneurship, 9(1), 1-20. Doi: 10.1186/s13731-020-0115-X 
Nelson, H., \& Stolterman, E. (2012). The design way: International change in an unpredictable world. The MIT Press.

Nguru, M., \& Maina, S. (2020). Socio-cultural impact of beadwork in East Africa: the nexus between the Dinka Samburu and Maseai ethnicities. International Journal of Innovative Research and Development, 9(7), 87-94. Doi: 10.24940/ijird/2020/v9/17/jw

Ogundele, M. O., Oparinde, F. O., \& Moronfoye, S. A. (2013). Entreprenership Education: A Panacea for Secondary Schools Transformation in Nigeria. European Journal of Education Sciences, 1(1), 46-52. ISSN: 1857-6036.

Pertuz, V., \& Pérez, A. (2020). Innovation management practices: review and guidance for future research in SMEs. Management Review Quarterly, 1-37. Doi: 10/007s11301-020-00183-9

Pisano, G. P. (2019).The hard truth about innovation. Harvard Business Review, 62-71. Retrieved from: https://hbr.org/2019/01/the-hard-truth-about-innovativecultures.

Ranjana, U. (2014). A Comparative study of colour preferences towards clothing among young girls and boys, (Unpublished Seminar talk of the department of Home Economics Science dissertation), Institute of excellence in higher education, Bhopah

Ratten, V., \& Jones, P. (2020). Entrepreneurship and management education: Exploring trends and gaps. The International Journal of Management Education, 100431. Doi: 10.1016/jijme.2020.100431.

Rico, M., Camara, C., \& LIamazares, M. (2015). Impacto de la Education enal empren dimeiento making of y analysis de tres grupos de discussion. Pedagogia Social, 25, 221-224. ISSN: 1139-1723.

Splendor. (2014). Migration of bead making and beadwork throughout Africa. Retrieved from: http://www.smithsoniaeducation.org/migration/beads/essay.htm

The Guardian. (May, 2015). Nigerian woman with no formal education but lectures at Harvard and other top Universities. Retrieved from: https://guardian.ng/news/nigerian-woman-with-no-formal-education-butlectures-at-harvard-other-top-varsities/

Tomitta, K. (2005). Principles and elements of visual design: A review of the literacy design of instructional materials. Educational Studies, 57. International Christian University.

Ware, C. (2008). Visual Thinking for Design. Burlington: Morgan Kaufmann

Wolfe, M. (2010). The degree to which colour is associated with mood stores. Journal of Applied Psychology, 6, 432-435.

Wuritta, E.G., Dung, Z.E., \& Musa, S. (2014). Facilitating beads-making through computer-aided design. Advancement in Scientific and Engineering Research, 2(4), 70-75. 


\section{Appendix}

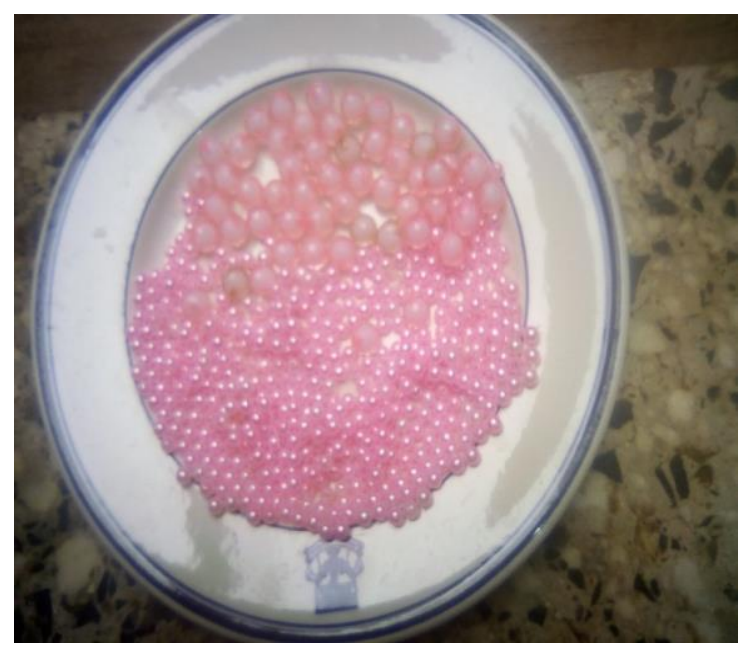

Plate 1.1: Beads (small and big)

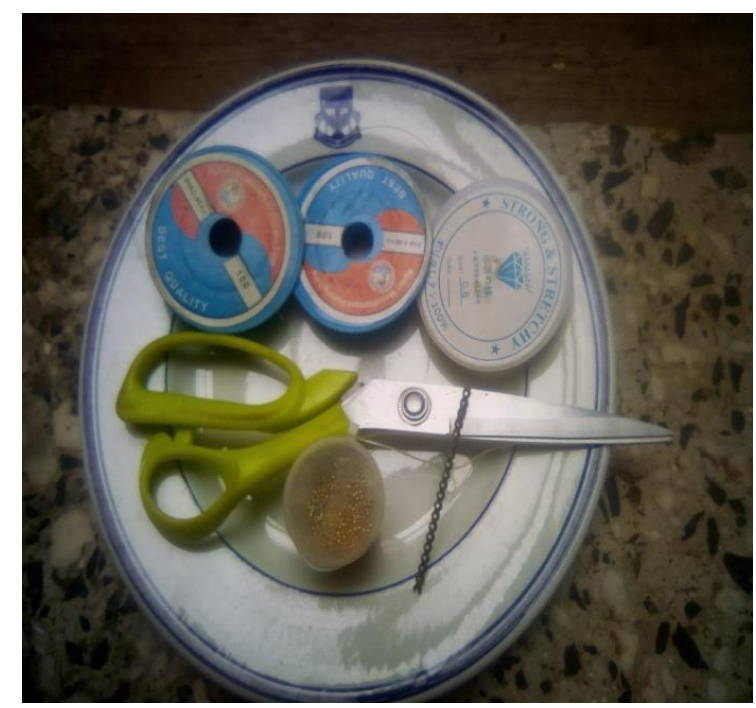

Plate 1.3: Materials used.

Belt

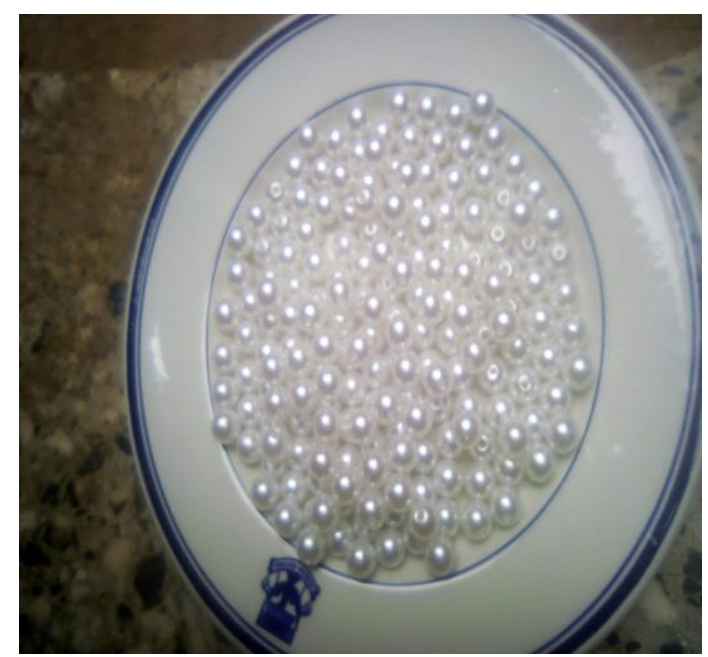

Plate 1.2: Beads (Big).

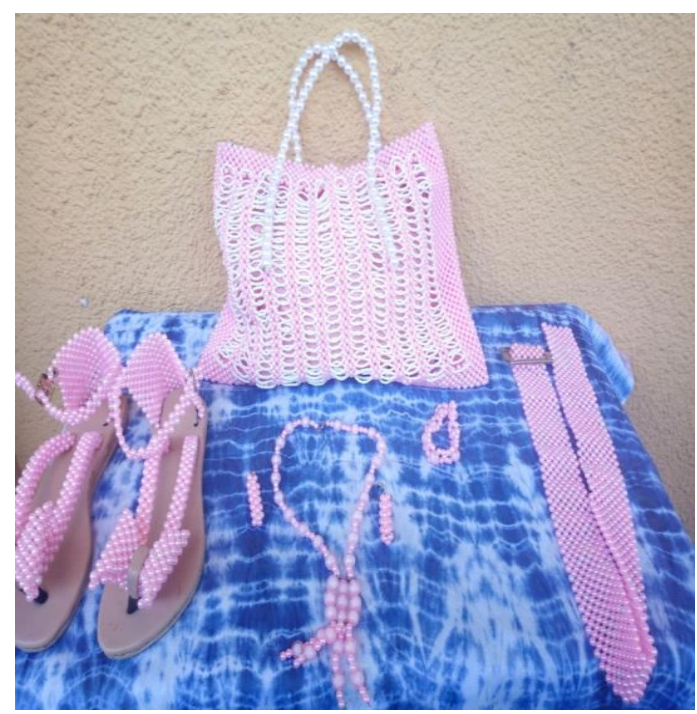

Plate 2.1: Finished self-samples:

Bag, Necklace and Sandal. 


\section{Appendix (continues)}

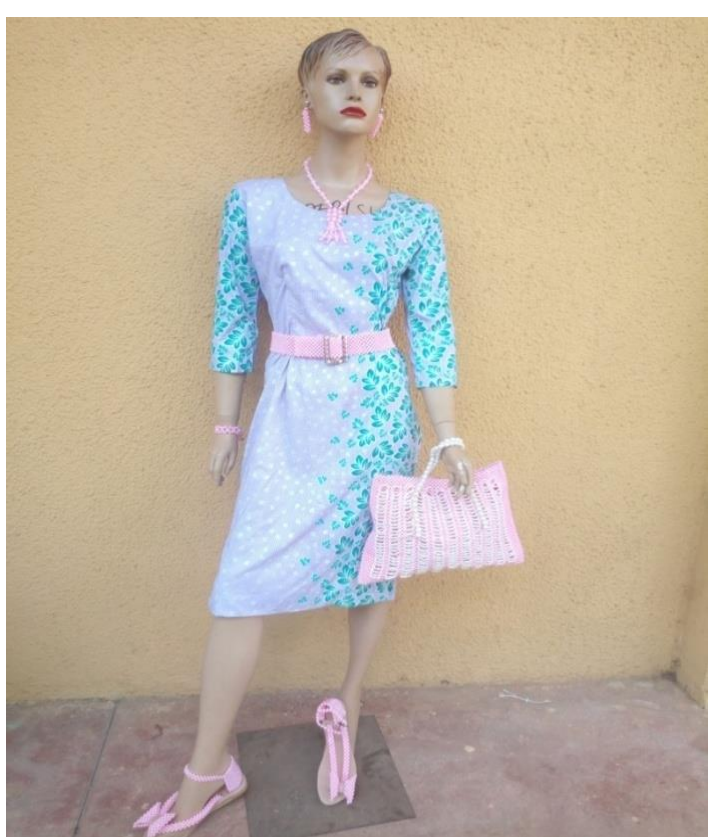

Plate 3: Displayed self-samples: beaded Jewelry 